TIME TRAVELS 


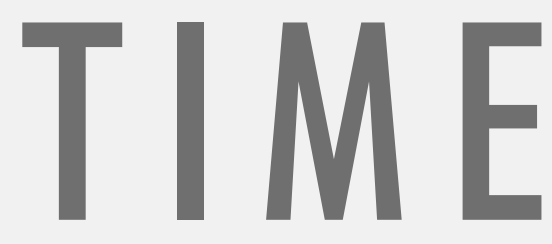

NEXT WAVE: NEW DIRECTIONS IN WOMEN'S STUDIES

A series edited by Inderpal Grewal, Caren Kaplan,

and Robyn Wiegman 


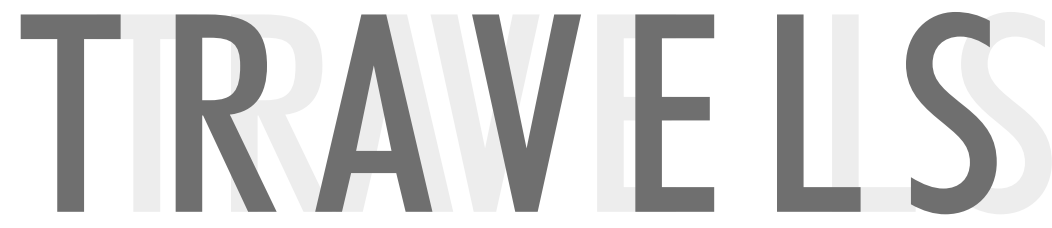

Feminism, Nature, Power

\section{ELIZABETH GROSZ}


@2005 Duke University Press

All rights reserved

Printed in the United States

of America on acid-free paper @

Designed by Amy Ruth Buchanan

Typeset in Minion by Tseng Information

Systems, Inc. Library of Congress

Cataloging-in-Publication Data and

republication acknowledgments appear

on the last printed pages of this book. 